\title{
Digitalizovaná sbírka starých tisků je převáděna do nového systému
}

Knihovna PF UK od poloviny roku 2011 zpř́stupňuje pro zájemce vybrané digitalizované prameny české právní vědy z fondu knihovny. Digitalizované texty jsou momentálně zveřejněny v systému DigiTool, který je již zastaralý a uživatelsky nekomfortní. Proto bychom rádi převedli tuto sbírku do novějšího systému Kramerius, který začala Ústřední knihovna UK provozovat pro všechny fakultní knihovny.

Tento převod digitálních objektů jsme již zahájili ve spolupráci s Ústřední knihovnou UK a projekt jsme rozdělili do následujících tř́i etap:

1) V první etapě jsme začali př́mo do Krameria vkládat digitalizovanou sbírku patentů z let 1745-1829, která je uložena ve fondu knihovny. Část sbírky je už pro zájemce $\mathrm{k}$ dispozici a můžete ji nalézt na adrese http://kramerius.cuni.cz/historickePravo. Vkládání dalších patentů průběžně pokračuje. Také případné další nově digitalizované tisky budou zpracovávány př́mo do Krameria.

2) V druhé etapě bude ze systému DigiTool do Krameria převedeno sedm již digitalizovaných starých tisků. Tato fáze přesunu bude vyžadovat určitou přípravu a bude to poměrně náročný proces, protože některá díla (např. Constitutio criminalis Theresiana) jsou značně rozsáhlá.

3) Ve třetí etapě plánujeme do Krameria převést i všech 66 svazků Zákoníku říšského, což znamená zpracovat přibližně 35000 stran. Tato konverze bude nejnáročnější a zatím není stanoven termín zahájení ani ukončení této fáze projektu. Nejprve bude nutné připravit metodiku a vytvořit program, který konverzi Zákoníku do Krameria umožní. Můžeme tedy předpokládat, že ještě několik let bude Zákoník říšský uživatelům k dispozici v systému DigiTool.

Věříme ale, že postupně bude celá digitalizovaná historická sbírka Knihovny PF UK převedena do systému Kramerius a že se bude nadále rozšiřovat. Předpokládáme také, že práce s digitalizovanými objekty bude pro uživatele v systému Kramerius jednodušší a zajímavější, protože ovládání je velmi intuitivní.

Mgr. Radka Kovářová

Vedoucí knihovny, Univerzita Karlova, Právnická fakulta

Kontaktní e-mail: kovarova@prf.cuni.cz

doi: $10.14712 / 2464689 X .2021 .14$ 